\title{
Rancang Bangun Sistem Monitoring Environment Area Tempat Tinggal Mahasiswa Berbasis IoT
}

\author{
Alfiana Intan Karisma ${ }^{1}$, Fachrul Kurniawan ${ }^{2}$, Ajib Hanani ${ }^{3}$
}

\begin{abstract}
Abstrak- Pencemaran udara muncul menjadi masalah di kota-kota besar seperti pada kota Malang. Kota Malang dikenal sebagai kota Pendidikan, banyak mahasiswa dari luar kota yang menimba ilmu di kota ini. Bertambahnya penghuni maka peningkatan aktivitas manusia akan semain banyak dan menjadi salah satu penyebab pencemaran udara. Pencemaran udara mengandung gas-gas berbahaya seperti gas buang kendaraan bermotor dan asap pabrik, sehingga akan berdampak negatif bagi kesehatan manusia. Hal tersebut dapat diminimalisir dengan dibuat sebuah sistem monitoring lingkungan area tempat tinggal mahasiswa berbasis Internet $O f$ Things (IoT) yang berada disekitar kampus UIN Malang. Perancangan sistem ini bertujuan untuk memberi informasi tingkat kualitas udara yang berasal dari gas buang kendaraan bermotor dan aktivitas gerakan yang terekam disekitar lingkungan tempat tinggal mahasiswa dengan menggunakan teknologi IoT. Alat yang digunakan yaitu sensor MQ-7, Mikrokontroller NodeMCU dan kamera web. Sistem database menggunakan database MSQL dan informasi data berupa grafik dalam aplikasi berbasis web. Setiap sensor gas memiliki tingkat akurasi yang berbeda-beda, untuk mengukur keakuratan sensor MQ-7 menggunakan perhitungan dari rumus Mean Absolute Percentage Error (MAPE). Sensor MQ-7 memiliki nilai akurasi sebesar $58,9 \%$ dengan nilai kesalahan $41,1 \%$.
\end{abstract}

Kata Kunci-Sensor MQ-7; NodeMCU;Monitoring;IoT.

Abstract - Air pollution appears to be a problem in big cities like in the city of Malang. Malang City is known as an Education City, many students from outside the city are studying in this city. The increase in occupants will increase the amount of human activity and will become one of the causes of air pollution. Air pollution contains harmful gases such as motor vehicle exhaust gases and factory fumes, which will negatively impact human health. This can be minimized by creating a system of environmental monitoring of the area of residence of students based on the Internet of Things (IoT) located around the campus of UIN Malang. The design of this

Alfiana Intan Karisma is with the Informatic Engineering Departement of Universitas Islam Negeri Maulana Malik Ibrahim Malang, Indonesia, (email alfianaintan22@gmail.com).

Fachrul Kurniawan, was with the Informatic Engineering Departement of Universitas Islam Negeri Maulana Malik Ibrahim Malang, Indonesia.

Ajib Hanani is the Informatic Engineering Departement Universitas Islam Negeri Maulana Malik Ibrahim Malang, Indonesia. system aims to provide information on the level of air quality derived from motor vehicle exhaust gases and recorded movement activities around the student's residence environment using IoT technology. The tools used are MQ-7 sensor, NodeMCU microcontroller and web camera. The database system uses an MSQL database and graphical data information in a web-based application. Each gas sensor has a different level of accuracy, to measure the accuracy of the MQ-7 sensor using calculations from the Mean Absolute Percentage Error (MAPE) formula. MQ-7 sensor has an accuracy value of $58.9 \%$ with an error value of $41.1 \%$.

Keyword-MQ-7; NodeMCU; Monitoring; IoT.

\section{PENDAHULUAN}

$\mathrm{L}$ ingkungan sehat adalah lingkungan yang memiliki $\Lambda_{\text {kualitas udara yang baik. Udara mengandung }}$ oksigen yang dibutuhkan oleh setiap makhluk hidup. Selain oksigen, udara mengandung zat-zat lain seperti karbon monoksida, karbon dioksida, virus, debu dan sebagainya. Pencemaran udara merupakan kondisi ketika kualitas udara menjadi rusak dan terkontaminasi oleh zat-zat yang tidak baik bagi kesehatan manusia. Pencemaran udara terjadi akibat dari ulah manusia dan dapat terjadi karena kejadian alam [1].

Kota Malang dikenal sebagai kota pendidikan, banyak mahasiswa dari luar kota bahkan dari luar jawa yang menimba ilmu di kota ini. Hal tersebut memberi banyak perubahan pada kota Malang. Bertambahnya penghuni maka peningkatan aktivitas manusia akan semakin banyak yang kemudian menjadi penyebab masalah pencemaran udara. Pencemaran udara tersebut akan menyebabkan penurunan kualitas udara yang berdampak negatif pada kesehatan manusia itu sendiri. Aktivitas ligkungan kost-kostan selama ini luput dari pengamatan terhadap keadaan lalu lintas. Karena kostkostan merupakan penyumbang secara langsung polusi yang ada di kota Malang.

Penelitian ini menggunakan sensor polusi yaitu sensor MQ-7 dan kamera web untuk mengetahui tingkat polusi udara dan aktivitas gerakan di lingkungan sekitar kost-kostan. Data yang telah diperoleh akan dikirim melalui mikrokontroler arduino. Data tersebut kemudian diolah dan menjadi sebuah sistem yang nantinya akan memberikan informasi melalui internet mengenai kualitas udara dan kepadatan aktivitas mahasiswa pada waktu tertentu. 
Tujuannya yaitu untuk memberi informasi mengenai tingkat polusi udara apakah semakin meningkat atau sebaliknya polusi udara berkurang, dan dapat merekam data kualitas udara melalui Internet of Things. Apabila polusi udara semakin meningkat alat ini dapat digunakan sebagai media informasi kepada penghuni kost-kostan. Sehingga penghuni dengan cepat dapat menangani masalah kenaikan polusi dan dapat bertindak dengan tepat agar lingkungan sekitar kost-kostan tetap menjadi lingkungan yang sehat. Dengan demikian, penelitian ini membuat sebuah alat monitoring untuk memantau kualitas udara di lingkungan sekitar kampus UIN Malang. Tujuannya yaitu untuk memberi informasi mengenai tingkat polusi udara apakah semakin meningkat atau sebaliknya polusi udara berkurang, dan dapat merekam data kualitas udara melalui Internet of Things.

\section{LANDASAN TEORI}

\section{A. Internet Of Things}

Internet of Things pertama kali diperkenalkan pada tahun 1999 oleh Kevin Asthon. Penerapan IoT dalam berbagai bidang banyak ditemukan dalam kehidupan sehari-hari pada manusia. Menurut CISCO, telah menargetkan bahwa pada tahun 2020, 50 miliar objek akan terhubung dengan internet [2].

Internet of Things atau IoT merupakan perkembangan keilmuan yang menjanjikan untuk mengoptimalkan dalam kehidupan yang mana mampu dalam memindahkan data melalui jaringan, sehingga interaksi manusia langsung dengan computer menjadi satu arah. Menggunakan sensor cerdas dan peralatan pintar yang bekerjasama melalui jaringan internet. Penggunaan IoT memungkinkan bagi pengguna untuk mengelola data dengan mengoptimalkan peralatan eleketronik dan peralatan listrik yang menggunakan internet. Hal ini akan memberikan keuntungan dalam komunikasi antar komputer dengan peralatan elektronik pada saat terjadi pertukaran informasi. Kemudian bagi pengguna internet juga akan semakin meningkat dengan berbagai fasilitas dan layanan internet [3].

\section{B. Mean Absolute Percentage Error (MAPE)}

Mean Absolute Percentage Error (MAPE) adalah sebuah perhitungan ukuran yang memiliki kesalahan relatif. Persamaan dalam MAPE digunakan untuk menghitung kesalahan-kesalahan terhadap permintaan actual selama periode tertentu dan hasilnya kemudian dikalikan $100 \%$ agar mendapatkan hasil dalam bentuk persentase [4]. Rumus MAPE dalam perhitungannya menggunakan kesalah absolut pada tiap periode kemudian dibagi dengan nilai hasil observasi yang diambil secara langsung (nyata) pada waktu periode tersebut. Selanjutnya menghitung nilai rata-rata kesalahan persentase absolut tersebut.

Metode MAPE berguna dalam mengevaluasi ketepatan ramalan pada saat pengukuran atau besar sebuah variabel. MAPE dapat mengidentifikasi seberapa besar nilai kesalahan dan meramal yang dibandingkan dengan nilai nyata pada suatu deret. Metode $M A P E$ juga dapat digunakan dalam perhitungan untuk membandingkan ketepatan dari metode yang sama atau metode yang berbeda dalam dua deret yang berbeda. $M A P E$ dapat dihitung dengan rumus sebagai berikut [5].

MAPE $=\frac{1}{n} \sum_{\mathrm{i}=1}^{n} \frac{\left|y_{t}-\hat{y}_{t}\right|}{y_{t}} \times 100 \%$

\section{Sistem Monitoring}

Sistem monitoring merupakan proses berlangsunya pemberian informasi untuk menetapkan langkah menuju kearah perbaikan yang berkesinambungan. Pelaksanaannya, monitoring dilakukan ketika suatu proses sedang berlangsung. Acuan level kajian yaitu pada kegiatan dalam suatu bagian proses transaksi maupun kegiatan struktural [6].

Terdapat beberapa tujuan sistem monitoring. Tujuan sistem monitoring dapat ditinjau dari beberapa segi, misalnya segi obyek dan subyek yang dipantau, serta hasil dari proses monitoring itu sendiri.

\section{Sensor MQ-7}

Sesnsor MQ-7 merupakan alat untuk mendeteksi tingkat kandungan karbon monoksida (CO). sensor ini memiliki tingkat kepekaan yang tinggi terhadap gas $\mathrm{CO}$ dan hasil kalibrasinya stabil serta tahan lama. Saat dilakukan deteksi gas CO di udara oleh sensor ini, tegangan output pada sensor ini akan meningkat. Berikut adalah gambar 1 yang menunjukan sensor MQ7.

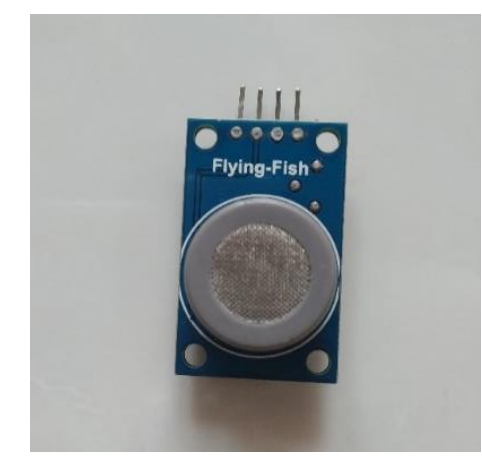

Gambar 1. Sensor MQ-7

\section{E. Mikrokontroler NodeMCU}

Nodemcu merupakan salah satu firmware dari modul ESP8266 yang memiliki sifat open source dan memiliki pengembangan kit yang bertujuan untuk memudahkan membangunan prototype produk Internet of Things (IOT) dengan menggunakan bahasa pemograman scriptins Lua. Nodemcu adalah mikrokontroler yang sudah dilengkapi modul ESP8622 di dalamnya. Seperti Arduino akan tetapi nodemcu memiliki kelebihan sudah memiliki WiFi.

ESP8266 merupakan modul WiFi yang berfungsi sebagai perangkat tambahan mikrokontroler seperti Arduino agar dapat terhubung langsung dengan WiFi dan membuat koneksi TCP/IP [7]. ESP8266 memiliki kemampuan on-board prosesing dan storage yang memungkinkan dengan aplikasi alat tertentu melalui sebuah pin input dan pin output hanya dengan 
pemograman singkat. Berikut adalah gambar 2 yang menunjukan Mikrokontroler NodeMCU.

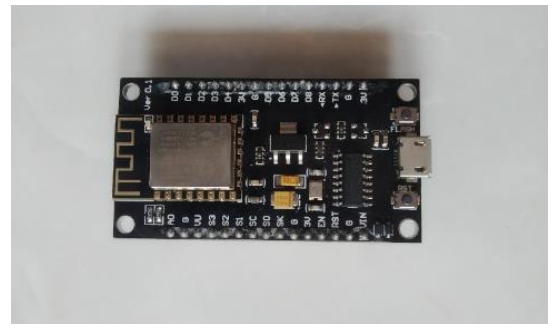

Gambar 2. Mikrokontroler NodeMCU

\section{F. Kamera Web}

Kamera web merupakan kamera video digital kecil yang dihubungkan pada komputer melalui port USB atau port COM. Fungsi dari webcam itu sendiri yaitu untuk memudahkan dalam mengolah pesan cepat seperti chat melalui video secara lamgsung dengan cara bertatap muka [8]. Dalam penelitian ini menggunakan kamera web yang ditunjukan pada gambar 2.3 di bawah ini.

\section{PERANCANGAN SISTEM}

\section{A. Desain Sistem}

Desain sistem ini mengacu pada tahapan proses yang ada pada sistem yaitu input, proses dan output. Input bahan penelitian berupa data kosentrasi gas dan aktivitas Gerakan, proses sebagai pemroses bahan penelitian dan output sebagai hasil keluaran dari proses. Desain sistem yang dilakukan mengikuti proses seperti pada gambar 3 .

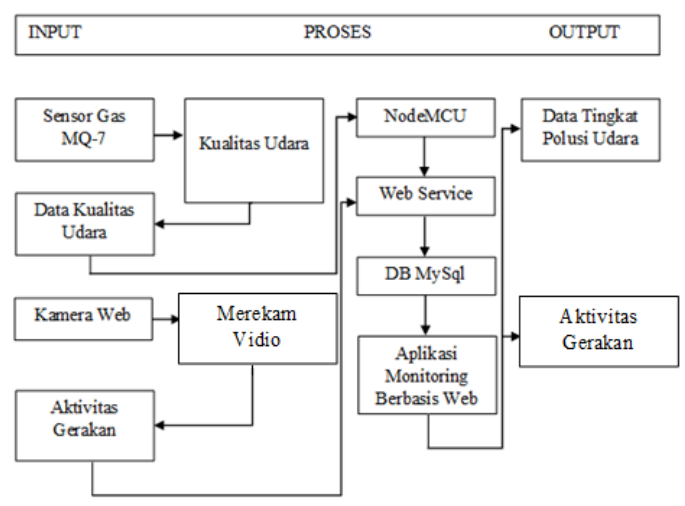

Gambar 3. Desain Sistem

\section{B. Alat dan Bahan Penelitian}

- Perangkat Keras

Perangkat yang digunakan untuk pengembangan aplikasi, yaitu laptop dengan spesifikasi sebagai berikut:

1. Intel Core i5 3230M @ 2.60GHz

2. RAM $2 \mathrm{~GB}$

3. Monitor 14 " dengan resolusi $1366 \times 768$ Perangkat yang digunakan sebagai bagian dari sistem, yaitu:
1. Sensor MQ-7
2. Webcam
3. NodeMCU
4. AP TP-LINK MR 3020
5. Modem
6. Kabel

- Perangkat Lunak

Perangkat lunak untuk pengembangan program pada sistem dalam penelitian ini, yaitu:

1. Sublime text

2. PHP

3. MySQL

4. Apache

5. Aplikasi Webcam 7

6. Arduino IDE

7. FileZilla FTP Client

\section{Perancangan Hardware dan Software}

Sistem yang dikerjakan yaitu perancangan sistem hardware. Gambar blok diagram rancangan rangkaian alat (hardware) terdapat pada gambar 4 di bawah ini.

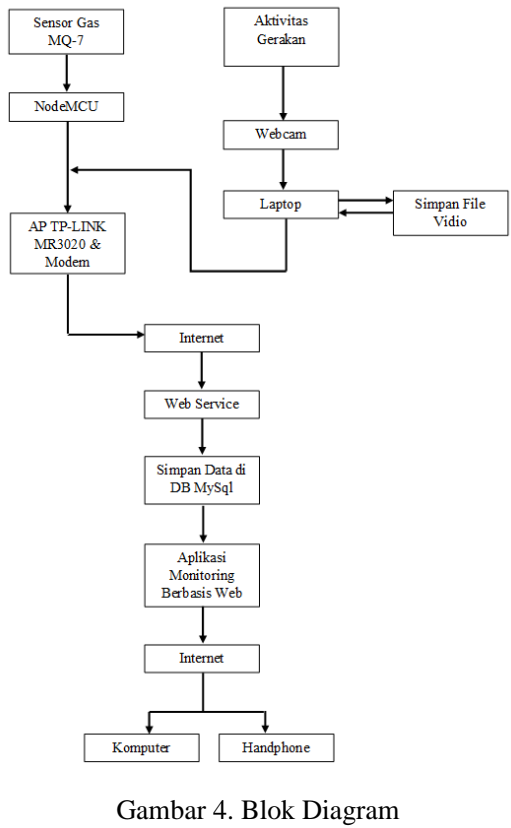

Dari blok diagram rangakaian alat di atas menjelaskan mengenai prototipe perangkat keras maupun komponen yang terkoneksi dengan IoT, penjelasanya adalah sebagai berikut:

- Input Kualitas Udara

1. Sensor gas MQ-7 mendeteksi karbon monoksida (CO)

2. Data CO tersimpan di nodemcu, data berupa jumlah karbon monoksida dan waktu pengukuran.

3. Menggunakan media penghubung Access Point TP-LINK MR3020 dan modem untuk mengirimkan informasi ke database.

- Input Aktivitas Gerakan

1. Kamera web merekam setiap aktivitas gerakan.

2. Data aktivitas gerakan berupa file motion disimpan di laptop, data berupa jumlah file dan waktu pengambilan file.

3. Menggunakan media penghubung Access Point TP-LINK MR3020 dan modem untuk mengirimkan informasi ke database.

- Proses

1. Semua data dari jumlah karbon monoksida, gerakan dan waktu masuk ke web service. 
2. Penyimpanan dilakukan pada database MySql

- Output

Data ditampilkan pada aplikasi monitoring berbasis web berupa grafik gas karbon monoksida dan aktivitas gerakan.

Pada penelitian rancang bangun sistem monitoring environment area tempat tinggal mahasiswa berbasis internet of things (IoT) membutuhkan beberapa perangkat lunak seperti Arduino IDE dan Webcam7. Software Arduino IDE digunakan pada rancang bangun monitoring dalam mendeteksi tingkat gas karbon monoksida (CO) sebagai software yang mengintregasikan Bahasa $\mathrm{C}$, Bahasa $\mathrm{C}++$ atau bahasa pemograman mikrokontroler yang lainya. Sehingga menjadikan bahasa lebih mudah dipahami dan diolah oleh manusia.

Software webcam7 digunakan dalam pengambilan data gerak pada area tempat tinggal mahasiswa disekitar kampus UIN Malang. Pada aplikasi webcam7 ini menggunakan fitur motion detection yang berfungsi sebagai pengambilan gambar ketika kamera mendeteksi gerakan secara otomatis dan hasil dari pengambilan data yaitu berupa file avi (video).

\section{Rencana Pengujian}

Pengukuran tingkat akurasi sensor MQ7 dapat diketahui dengan menghitung nilai kesalahan. Untuk mengetahui nilai kesalahan (error), maka terlebih dahulu mencari nilai ppm dengan mengetahui nilai Rs (Resistance of Sensor) dan Ro (Resisance of Oksigen) terlebih dahulu. Standar Rs/Ro yang digunakan dalam perhitungan untuk mencari nilai ppm yaitu $\mathrm{y}=26.977$ [9]. Sebelum mencari nilai Rs maka terlebih dahulu mencari Vout nya dengan menggunakan rumus di bawah ini.

$$
\text { Vout }=A d c \times \frac{\text { Vde }}{\operatorname{Max} A d c}
$$

Selanjutnya mencari nilai Rs, dimana nilai Rs dapat dicari dengan rumus berikut.

$$
R s=\left(\frac{\text { Vex RL }}{\text { Vout }}-R L\right)
$$

Keterangan :

Rs : Hambatan sensor MQ-7

Vc : Tegangan sirkuit

Vout: Tegangan keluar

RL : Hambatan beban

Kemudian menghitung nilaiRs/Ro dengan Ro $=830$, kemudian mencari nilai ppm dengan rumus sebagai berikut.

$$
p p m=\left(26.977 /\left(\frac{R s}{R 0}\right)\right)^{-0.66}
$$

\section{PEMBAHASAN}

\section{A. Implementasi}

Pada grafik terdapat dua informasi yang ditampilkan, yang pertama yaitu tampilan grafik perhari merupakan grafik yang menampilkan dua data yaitu rata-rata dari data gas CO dan jumlah gerakan yang diambil dari setiap harinya. Berikut adalah tampilan dari grafik perhari yang ditunjukan pada gambar 5 .

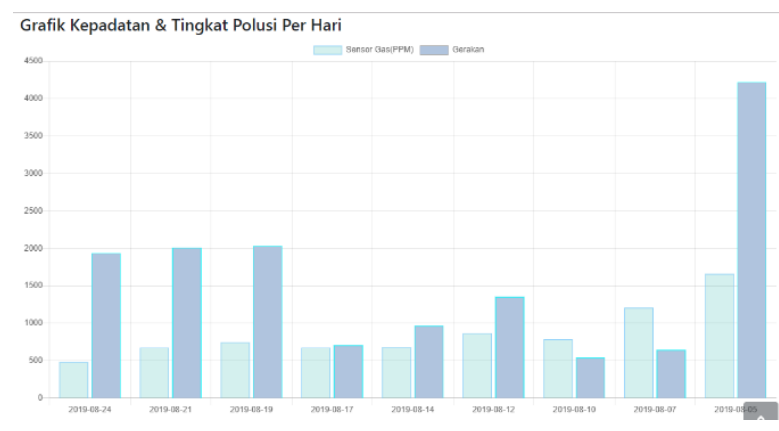

Gambar 5. Grafik Perhari

Kedua yaitu tampilan grafik perwaktu merupakan data yang diambil dari rata-rata gas $\mathrm{CO}$ dan jumlah untuk data gerakan dalam waktu pengambilan yang sudah ditentukan, yaitu Pukul 07.00-08.00 WIB, 12.0013.00 WIB dan 16.00-17.00 WIB. Berikut adalah tampilan grafik perwaktu yang ditunjukan pada gambar 6.

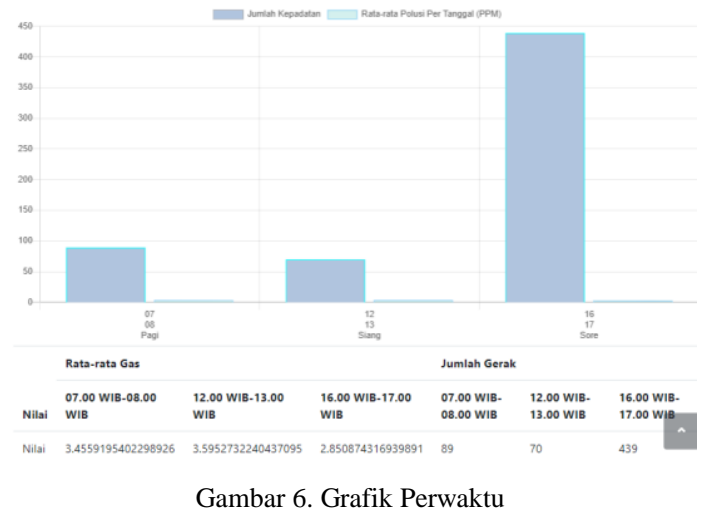

\section{B. Pengujian Sensor MQ-7}

Pengujian ini dilakukan untuk mengetahui tingkat akurasi dari sensor MQ-7. Berikut adalah tabel 1 yang menunjukan perbandingan antara data dari alat dan nilai datasheet untuk mengetahui nilai kesalahan sehingga dapat menghitung nilai tingkat akurasi dari sensor MQ-

\begin{tabular}{|c|c|c|c|c|c|c|}
\hline No & $\begin{array}{l}\text { Nama } \\
\text { Jalan }\end{array}$ & Hari & $\begin{array}{c}\text { Waktu } \\
\text { Pengambilan }\end{array}$ & $\begin{array}{c}\text { Data dari } \\
\text { Alat } \\
(P P M)\end{array}$ & $\begin{array}{c}\text { Datasheet } \\
(P P M)\end{array}$ & $\begin{array}{c}\text { Error } \\
\text { (\%) }\end{array}$ \\
\hline \multirow{9}{*}{1.} & \multirow{9}{*}{$\begin{array}{c}\text { JL. Sunan } \\
\text { Kalijaga } \\
\text { Dalam }\end{array}$} & \multirow{3}{*}{ Senin } & $07.00-08.00$ & 3.06 & 2.89 & 6 \\
\hline & & & $12.00-13.00$ & 2.81 & 2.89 & 3 \\
\hline & & & $16.00-17.00$ & 2.97 & 2.89 & 3 \\
\hline & & \multirow{3}{*}{ Rabu } & $07.00-08.00$ & 3.45 & 2.89 & 20 \\
\hline & & & $12.00-13.00$ & 3.59 & 2.89 & 25 \\
\hline & & & $16.00-17.00$ & 2.85 & 2.89 & 1 \\
\hline & & \multirow{3}{*}{ Sabtu } & $07.00-08.00$ & 11.5 & 2.89 & 299 \\
\hline & & & $12.00-13.00$ & 4.17 & 2.89 & 45 \\
\hline & & & $16.00-17.00$ & 2.85 & 2.89 & 1 \\
\hline \multirow{9}{*}{2.} & \multirow{9}{*}{$\begin{array}{c}\text { Л. } \\
\text { Joyosuko }\end{array}$} & \multirow{3}{*}{ Senin } & $07.00-08.00$ & 3.02 & 2.89 & 5 \\
\hline & & & $12.00-13.00$ & 3.40 & 2.89 & 18 \\
\hline & & & $16.00-17.00$ & 3.29 & 2.89 & 14 \\
\hline & & \multirow{3}{*}{ Rabu } & $07.00-08.00$ & 3.43 & 2.89 & 19 \\
\hline & & & $12.00-13.00$ & 2.99 & 2.89 & 4 \\
\hline & & & $16.00-17.00$ & 2.92 & 2.89 & 1 \\
\hline & & \multirow{3}{*}{ Sabtu } & $07.00-08.00$ & 11.5 & 2.89 & 299 \\
\hline & & & $12.00-13.00$ & 3.11 & 2.89 & 8 \\
\hline & & & $16.00-17.00$ & 3.61 & 2.89 & 25 \\
\hline \multirow{9}{*}{3.} & \multirow{9}{*}{$\begin{array}{l}\text { JL. Kerto } \\
\text { Raharjo }\end{array}$} & \multirow{3}{*}{ Senin } & $07.00-08.00$ & 2.78 & 2.89 & 4 \\
\hline & & & $12.00-13.00$ & 3.74 & 2.89 & 30 \\
\hline & & & $16.00-17.00$ & 4.03 & 2.89 & 40 \\
\hline & & \multirow{3}{*}{ Rabu } & $07.00-08.00$ & 4.29 & 2.89 & 49 \\
\hline & & & $12.00-13.00$ & 2.93 & 2.89 & 2 \\
\hline & & & $16.00-17.00$ & 3.90 & 2.89 & 35 \\
\hline & & \multirow{3}{*}{ Sabtu } & $07.00-08.00$ & 4.30 & 2.89 & 49 \\
\hline & & & $12.00-13.00$ & 4.50 & 2.89 & 56 \\
\hline & & & $16.00-17.00$ & 4.29 & 2.89 & 49 \\
\hline \multicolumn{6}{|c|}{-rata presentase } & 41,1 \\
\hline
\end{tabular}
7.

Tabel 1. Data Akurasi 
Dari tabel di atas didapatkan hasil rata-rata presentase error menggunakan metode Mean Absolute Percentage Error (MAPE) sebesar $41,1 \%$ sehingga nilai keakurasian alat sensor MQ-7 pada peelitian ini sebesar $58,9 \%$.

\section{Pengambilan Data Gerak Kamera Web}

Proses pengambilan data dari kamera web ke direktori penyimpanan, yaitu dimulai dengan pengaturan pada aplikasi webcam7. Pengambilan data berupa file avi (video), sehingga dapat dikatakan bahwa satu gerakan adalah satu video. Apabila dalam satu video terdapat dua orang atau lebih, lewat secara bersamaan dalam satu waktu maka akan dihitung satu gerakan. Seperti pada gambar 7 pengambilan data gerak dengan motion detection yang terekam dalam satu video.

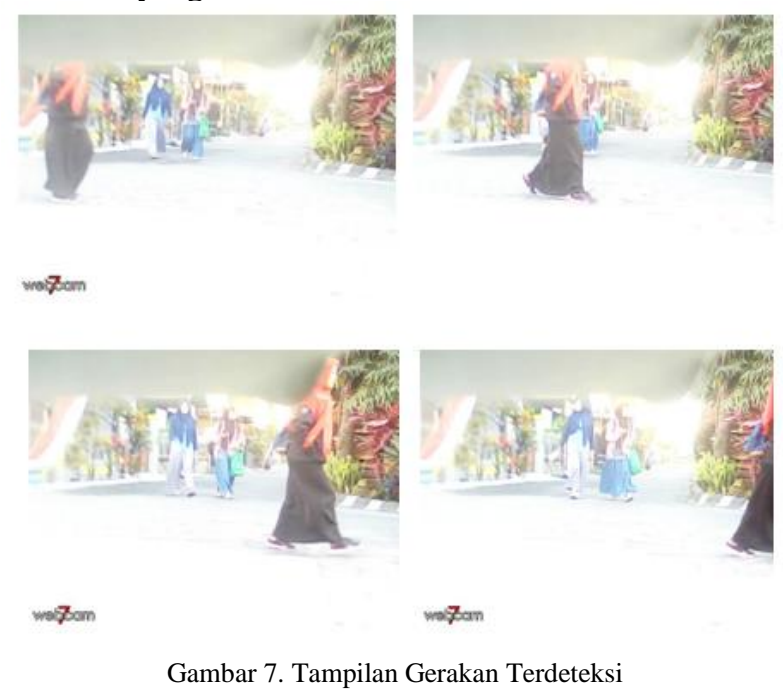

\section{KESIMPULAN}

Dari hasil perancangan dan pengujian sistem monitoring kualitas udara pada area tempat tinggal mahasiswa berbasis IoT dapat disimpulkan bahwa tingkat akurasi alat ukur dengan menggunakan sensor MQ-7 sebesar 58,9\% dengan nilai kesalahan (error) sebesar $41,1 \%$. Hasil pengukuran kadar gas karbon monoksida (CO) berhasil ditampilkan di situs jaringan secara real time dan online dengan alamat http://realmonitoring.web.id/index.php/product. Saran untuk penelitian selanjutnya, dalam pengambilan data lebih memperhatikan faktor angin, suhu dan kelembapan. Dengan menambahkan sensor-sensor yang mendukung dalam mengambilan data. Seperti sensor suhu dan sensor kelembapan. Untuk penelitian selanjutnya dalam pengambilan data dapat membandingkan hasil dari alat perancangan dengan alat yang sudah terkalibrasi. Misalnya seperti alat kalibrator yang bernama smart sensor karbon monoksida (CO) meter.

\section{REFERENSI}

[1]. Bella, G. K., Sastra, N. P., \& Hartawan, D. D. (2018). Prototipe Mobile. E-Journal SPEKTRUM.

[2]. Meutia, E. (2015). Internet of Things - Kemanan dan Privasi. Seminar Nasional dan Expo Teknik Elektro, 85-89.

[3]. Keoh, S. L., Kumar, S., \& Tschofenig, H. (2014). Securing The Internet of Things A Standardization Perspective. IEEE Internet of Things Journal.

[4]. Saputro, A. \&. (2016). Peramalan Perencanaan Produksi Semen Dengan Metode Exponential Smoothing Pada PT. Semen Indonesia. Industri Engineering.

[5]. Robbani, M. S. (2015). Rancang Bangun Perhitungan Jumlah Klorofil Pada Daun Kedelai Menggunakan Metode Fuzzy Mamdani. Malang: Universitas Islam Negeri Maulana Malik Ibrahim

[6]. Wrihatnolo, R. (2008). Monitoring, Evaluasi, dan Pengendalian: Konsep dan Pembahasan.

[7]. Yuliansyah, H. (2014). Uji Kinerja Pengiriman Data Secara Wireless Menggunakan Modul ESP8266 Berbasis Rest Architecture. Jurnal rekayasa dan Teknologi Elektro

[8]. Muslimin, Santoso, I., \& Sofwan, A. (2011). Monitoring Ruang Dengan Webcam Yang Dapat Diakses Melalui Handphone Menggunkan Jaringan WiFi.

[9]. Bahar, A. P. (2018). Rancang Bangun Alat Monitoring Polusi Udara pada Kawasan Industri berbasis Microkontroller Arduino Uno. Makasar: Politeknik Ati Makasar. 